\title{
Ecology, Economy, and Upland Landscapes: Socio-Ecological Dynamics in the Alps during the Transition to Modernity
}

\author{
Francesco Carrer ${ }^{1}$ (D) $\cdot$ Kevin Walsh ${ }^{2} \cdot$ Florence Mocci $^{3}$
}

Published online: 28 February 2020

(C) The Author(s) 2020

\begin{abstract}
Human interaction with mountain environments is generally perceived as an adaptation of local communities to the constraining ecological and morphological characteristics of their territory, a preconception challenged by many historians and ecologists yet still largely accepted for seasonally exploited uplands. Traditional upland seasonal practices are considered timeless and immutable as the mountain landscapes shaped by such practices. We combine the methodologies of landscape archaeology, ethnoarchaeology, and historical ecology in order to examine the validity of this assumption. Our analysis of two case studies from the French and Italian Alps between the eighteenth and the twenty-first century shows that socioeconomic dynamics affect the resilience of local montane ecosystems and the historical character of upland landscapes, and reveals that historical social, economic, and ecological driving forces contributed to upland landscape change, so that the sustainability of 'traditional' mountain land-use should not be presumed.
\end{abstract}

Keywords Landscape archaeology $\cdot$ Ethnoarchaeology $\cdot$ European Alps $\cdot$ Historical ecology $\cdot$ Uplands $\cdot$ Pastoralism $\cdot$ Traditional seasonal practices $\cdot$ Socioeconomic forces $\cdot$ Drivers of change $\cdot$ Italy $\cdot$ France

\section{Introduction}

The assessment of human-environment interaction in mountainous zones of Europe has long been reduced to simplistic discussions centred on the notion of adaptation of human communities to the constraining morphological and environmental characteristics of their territory (Guichonnet 1980). The lower arable yields (compared to intensively cultivated plains), combined with high altitude areas that can be exploited only during warmer months produced specific forms of human mobility. In addition, there is an

Electronic supplementary material The online version of this article (https://doi.org/10.1007/s10745-020-00130-y) contains supplementary material, which is available to authorized users.

Francesco Carrer

francesco.carrer@newcastle.ac.uk

1 McCord Centre for Landscape, School of History, Classics and Archaeology, Newcastle University, Newcastle upon Tyne NE1 7RU, UK

2 Department of Archaeology, University of York, King's Manor, York YO1 7EP, UK

3 Centre Camille Jullian UMR 7299, Aix Marseille Univ, CNRS, CCJ, Aix-en-Provence, France assumption that the dramatic topography constrained mobility within and across the Alps (Granet-Abisset 1997). As a consequence, many studies have suggested that economic intensification was not possible in mountain areas, that the majority of productive activities undertaken by local populations were for subsistence only, and that emigration was the only response to this fundamental dearth of endemic resources (e.g., (Braudel 1949)). These inferences were largely based on observations of Alpine communities during the latenineteenth and earlytwentieth centuries, when mountainous areas were experiencing economic marginalisation, high rates of poverty, and depopulation. These processes were triggered by dramatic socioeconomic transformations that started during the late-eighteenth century and led to a reorganisation of the economic strategies across Europe and to the rise of industrialisation. Acknowledgement of the impact of these processes on mountain communities led several historians and anthropologists to address the complex historical dynamics at the origin of mountain economies, cultures, and identities.

These scholars (e.g., (Rosenberg 1988; Viazzo 1989)) suggested that during the historic period, Alpine communities were not isolated entities, but were subject to the same social, economic, and political processes as rural communities in the plains, particularly over the last three centuries when growing intensity of land exploitation along with increasing expansion of markets were significantly changing rural communities, as was evident in 
the landscape. The socioeconomic history of the Alps was thus recognised as integrated with the wider political and socioeconomic history of Europe (Mathieu 2009). Since the medieval period, and increasingly during the early-modern period (sixteenth-seventeenth century), land-reclamation in valley bottoms and terraces along valley slopes enabled the expansion of farmland devoted to crop production, as well as more specialised production for export to the wider market, including vineyards and orchards (Scaramellini and Varotto 2008). Economic recession experienced by some Alpine countries in later periods, as well as changes in their economic strategies, led to the abandonment or transformation of these "domesticated" areas. The size and residence patterns of permanent settlements were influenced by various historical factors, including, among others, demographic pressures, rural activities, and route networks. Midaltitude (1200-1800 m) landscapes were also shaped over time by human activities such as woodland clearance for grazing and hay-making, tree exploitation associated with mining, tree-crops such as chestnut, or the modification of the vegetative composition of forested areas through the construction of structures or infrastructures, including pathways and terraces (e.g., (Acovitsioti-Hameau 2015)).

On the other hand, upland landscapes ( $>1800$ masl) are still generally considered to be less affected by regional and supraregional socioeconomic transformations (Plieninger et al. 2006): 318) and are seasonally exploited by shepherds whose mobility is held by some scholars to be an adaptation to extreme and unproductive environments (Netting 1981). Pre-industrial land-use at high-altitude is usually described as 'traditional' by environmental scientists and landscape ecologists (see, e.g., (Eriksson 2011; Oteros-Rozas et al. 2013)) and considered the result of long-term socio-ecological processes, where the range of possible economic strategies is constrained by the environment and its productive potential. Palaeoenvironmental and archaeological research suggests that human impact on upland vegetation evolved over time (Festi et al. 2014; Walsh et al. 2014), but historical farming practices in sub-alpine environments are generally regarded as largely unchanged. This has led to the promotion of 'traditional' seasonal activities for sustainable management of high-altitude ecosystems aimed at supporting human livelihoods while maintaining the local more-than-human biosphere (Johnson et al. 2016; Marini et al. 2011). Our hypothesis, however, is that shifts in regional economic strategies or social transformations experienced by Alpine communities in historical times (and possibly earlier) have conditioned activities undertaken at high-altitude, thus changing the characteristics and intensity of the impact on upland environments and landscapes. Although environmental constraints and climate change must be considered, socioeconomic processes have as much of a key role in shaping upland landscapes as they have in the lowlands.

In light of the above, we investigate how modernity, with its complex and extensive economic structures, transformed environmental knowledge, economic activities, and associated practices in the Alpine region, and how this transformation influenced niche construction (Laland and O'Brien 2010) in fragile high-mountain environments over the last three centuries. To our knowledge, this the first example from an Alpine context that adopts a landscape archaeological approach combining archaeological site data, palaeoenvironmental evidence, written archives and ethnoarchaeological research. We aim to fully elucidate the evolution of humanenvironment interactions that allowed mountain communities to develop economic connections with the extra-local ("free market") economic structures that were one of the defining elements of Modernity (Wallerstein 2011) with a view to assessing the extent to which socioeconomic dynamics affected the resilience (the capacity to absorb disturbance) (Walker et al. 2004) of alpine/subalpine ecosystems and the historical character of high-altitude landscapes. Our goal is to challenge the general perception of pre-industrial land-uses in the mountains as unchanging or 'traditional,' and to restore their historical depth and complexity (Mathieu 2011).

\section{The Study Areas}

The two case-studies are in the French and Italian Alps and are characterised by similar physical geography but different strategies of upland exploitation: the Vallée de Freissinières in the Department of Hautes-Alpes (France), and the Val Maudagna in the Cuneo province (Italy) (Fig. 1). The main selection criteria were their proximity to one another, their geographical similarities and their separate jurisdictions, which provided the ideal framework to address the key question underlying this research, which is whether different socioeconomic processes can produce distinct management strategies and landscape characters in analogous upland areas.

The two valleys are approximately $120 \mathrm{~km}$ apart (as the crow flies) either side of the French-Italian border. Both valleys are oriented east-west, they share similar morphological characteristics (gorges, waterfalls, etc.), in part a product of geology and geomorphology. Val Maudagna (approximately $6 \mathrm{~km} \mathrm{long)}$ opens up smoothly towards the Po plain, and the main geological formation is limestone. The Vallée de Freissinières (approx. $11 \mathrm{~km}$ long) is a hanging-valley dropping into the Vallée de la Durance and the main geological formation is dominated by sandstones (gres $d u$ Champsaur). Being closer to the coast (approx. $40 \mathrm{~km}$ as the crow flies), Val Maudagna's weather conditions and climax vegetation are more typically Mediterranean than the Vallée de Freissinières. On the other hand, Freissinières has a higher maximum and average altitude than Maudagna: Miroglio, the highest hamlet in Maudagna, is at $807 \mathrm{~m}$, while Dormillouse, the highest hamlet in Freissinières, is at $1727 \mathrm{~m}$. In general terms, both these areas can be considered montane valleys, characterised by ecosystems that are stratified according to 

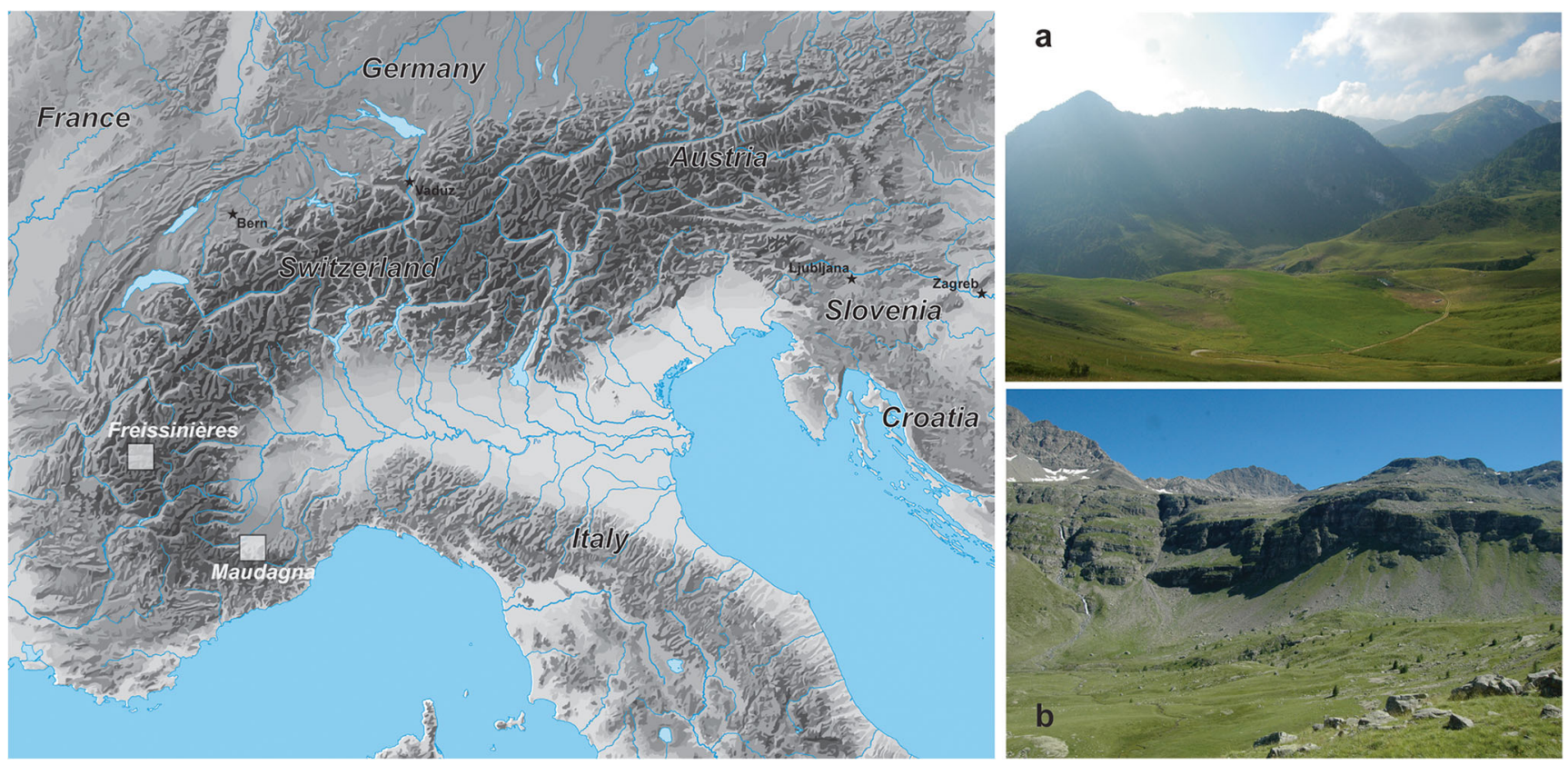

Fig. 1 Location of the study-areas and photos of the high-altitude pastures of Val Maudagna (a) and Vallée de Freissinières (b)

elevation. As with most mountain ranges, this vertical zoning leads to seasonal exploitation at different altitudes. The differences in socio-ecological interactions between the two areas derive mainly from their distinct institutional, economic, and cultural histories (see Supplementary Text 1 for a general historical overview).

As noted earlier, our study investigates how three centuries of changes in large-scale socioeconomic processes affected upland practices, and how the change of upland practices, in turn, led to a transformation of upland landscapes. In the Vallée de Freissinières, our analysis focuses on the area of the Montagne de Faravel (approx. 2000-2500 masl), encompassing the communal pastures of the Faravel plateau and the privately owned meadows of Fangeas, Pont de Fer, and Les Balmettes (Fig. 2). Administratively, all these pastures and meadows are part of the municipality of Freissinières. In the Val Maudagna, our analysis focuses on the area above Prato Nevoso (approx. 1650-1850 masl), corresponding to the pastures of Balma, Scalette, Seirasso, and Brignola (Fig. 3); the first is part of the municipality of Frabosa Sottana, the second of the municipality of Roccaforte Mondovì, whereas the last two are part of Magliano Alpi (we address this complex administrative pattern below).

\section{Methods}

We integrate the methodologies of landscape archaeology and ethno-archaeology within the interpretative framework of historical ecology (Balée 1998). During two fieldwork campaigns
(2013-2014), we carried out extensive archaeological surveys to record any evidence of human activities in the two study areas. We stored and managed the collected data using GIS, thus enabling standard spatial queries to be addressed. We paid particular attention to those features that characterise historical and modern landscapes and contribute to the reconstruction of their transformations and recent abandonment processes (Christie et al. 2007). Historical, geographical, and ethnographic literature, as well as documentary sources and historic maps from local and national archives in France and Italy, provided crucial insights on the evolution of rural strategies in the last three centuries. Both the study areas are still occupied by herders during the summer, thus enabling ethnoarchaeological investigation. Interviews and participant observation provided information that enhanced our understanding of local strategies at high-altitudes over the last century. If ethnoarchaeology is traditionally perceived as a method to create analog models or narratives for archaeological interpretation (David and Kramer 2001), recent research has highlighted its potential as a stand-alone approach for investigating ethno-historical processes (Skibo 2009). The combination of landscape archaeology and ethnoarchaeology has already proven useful for the reconstruction of landscape history in other Mediterranean rural areas (e.g., (Mientjes 2004; Pluciennik et al. 2004)). In previous research, socioeconomic transformations, political trends, and changes in cultural values were assigned a key role in landscape transformation. For this study, we added historical ecology to the picture. Seasonal exploitability and low yields (temperatures decrease by $0.6^{\circ}$ every $300 \mathrm{~m}$ of elevation, influencing pedogenesis and the length of vegetation period - (Walsh and Giguet-Covex 2019)) constrain the range of rural activities that can be carried out in the uplands, and for this 


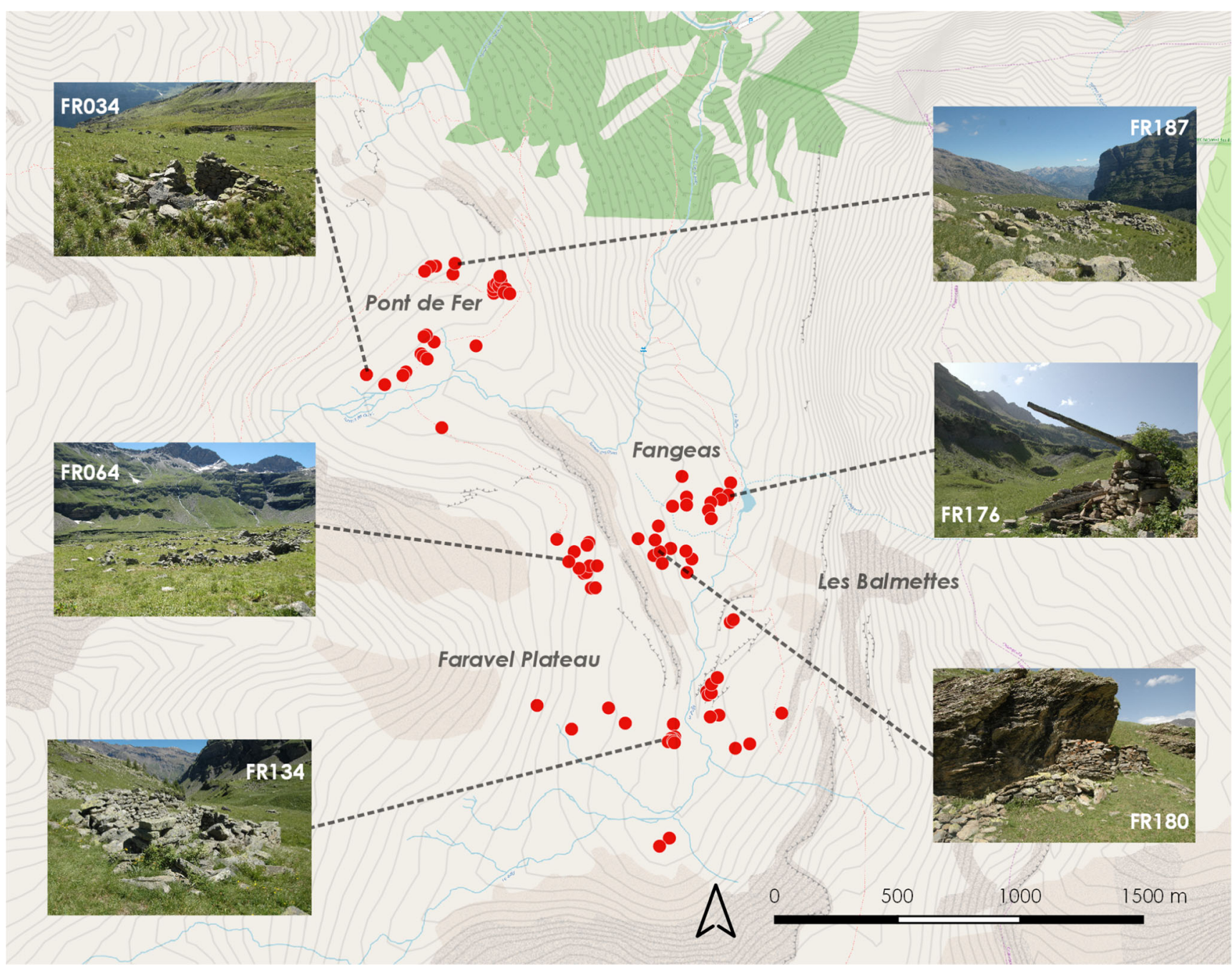

Fig. 2 Freissinières. Location of pastoral structures in the study-area, place names mentioned in the text and photos of the different types of structures recorded. Background: Open Street Map

reason the assessment of human interactions with the environment is essential to investigate correlations with other historical processes. We therefore correlated the evolution of upland landscapes with palaeoecological data available for the two study areas, highlighting fluctuations in human impact on mountain environments.

The main landscape features we identified in the studied areas were dry-stone huts, most currently abandoned, but some (especially in Val Maudagna) are still in use. They were recognised as hotspots of human activities, and therefore used here to infer the evolution of rural strategies at high-altitude. The first methodological challenge was the assessment of the chronology of construction and abandonment of these huts. Extensive excavation of all the recorded structures would not have been cost-effective, and the archaeological investigation of a sample of structures would not have provided representative outcomes. The characterisation or description of building techniques turned out to be unreliable since upland structures were more influenced by the locally available building material and characteristic of the terrain rather than by specific architectonic styles implemented in lowland permanent villages (Alther 2014). Although the chronology of the construction of these structures could not be easily inferred, the chronology of abandonment could instead be deduced. Specific preserved characteristics of the structures allowed us to create relative chronological phases that we then positioned on the timeline using ethnographic and historical information (see below for a detailed description).

\section{Vallée de Freissinières}

We examined historic documents and maps in the Archives Départementales des Hautes-Alpes in Gap (ADHA, PACA Region, France) to investigate social-ecological dynamics in the high-altitudes of Freissinières (Supplementary Text 2 - ADHA). In order to address changes that occurred in the valley during the twentieth century, we interviewed two 


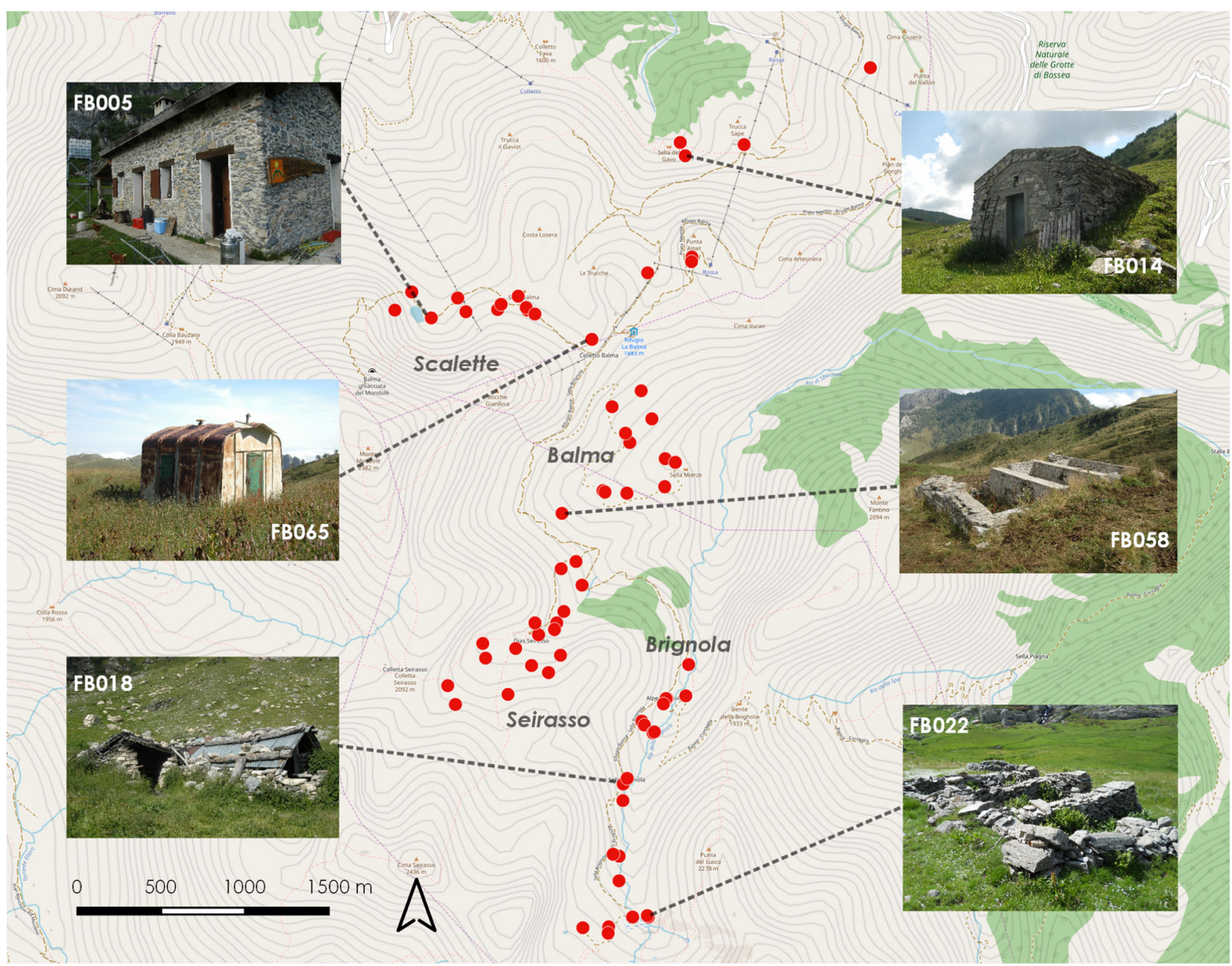

Fig. 3 Maudagna. Location of pastoral structures in the study-area, place names mentioned in the text and photos of the different types of structures recorded. Background: Open Street Map

members of the local community: a retired shepherd and former worker of the mine of L'Argentière-la-Bessée, living in the hamlet of Dormillouse, and a retired farmer living in the hamlet of Les Mensals, recommended, respectively, by the staff of the Parc des Écrins and residents of Freissinières, as the oldest residents and the most knowledgeable about the changes in upland livelihood strategies and landscapes in the last century. The interviews were semi-structured, and the answers were audio-recorded and transcribed. Large depopulation during the mid-twentieth century and recent immigration in the valley prevented the identification of a wider sample of experienced stakeholders. On the other hand, given the young age and limited experience of current transhumant shepherds working in the valley, we concluded that participant observation was not necessary to complement the information gathered during the interviews.

Archaeological and palaeoecological data have been collected from the upland landscapes and environments of
Freissinières over the last two decades. Pollen data from a peat core adjacent to the Fangeas lake and archaeological sites in the Faravel plateau suggest that the study area (Montagne de Faravel) was seasonally occupied by human groups since the early Holocene, and that different human strategies (pastoralism, hay-making, mining, etc.) contributed to transforming the environment and shaping the landscape (Walsh et al. 2014). We consider the latest phases of the pollen diagram from Fangeas in this research, along with the anthracological data from archaeological excavations and geoarchaeological coring in the surrounding areas. We used the pollen diagram from Serre de l'Homme lake (L'Argentière-la-Bessée) as a control sample and to provide more general inferences about the environmental transformations in the Durance valley. We carried out two archaeological survey campaigns in 2013 and 2014 and collected data specifically focused on the identification and analysis of historical ruderal landscape features and structures/infrastructures currently exploited that complements this rich archaeological dataset. 


\section{Upland Strategies Transformation}

Husbandry strategies in the Briançonais developed and specialized during the eighteenth and early nineteenth century (Rosenberg 1988; Arbos 1922; Garde et al. 2014; Vivier 1992). During the eighteenth century, the uplands were mostly occupied by chalets d'alpage where local farmers produced and stored dairy products. The increasing quantity of livestock in the first half of the nineteenth century, related to a generalized demographic growth, led to an increasing need for winter fodder and consequently to an extension of lowland meadows. The number of transhumant flocks from Provence summering in this district increased, and more upland pastures were rented to them rather than grazed by local farmers. This trend accelerated during the second half of the century as a consequence of the new forestry code, the contraction of the wool trade, and the progressive (but not uniform) transition to specialized cattle breeding for dairy production (fruitieres). These transformations proved to be economically unsustainable in the long term, and caused higher pressure on lowland meadows, a decreasing interest in upland meadows (marginal and with low yields), and abandonment of upland pastures (left almost entirely to transhumant shepherds) ((Arbos 1922): 91-99). Socioeconomic consequences of these processes were impoverishment, acceleration of permanent emigration, and loss of economic dynamism and resilience of rural communities. The main environmental consequences were soil depletion in the lowlands and loss of biodiversity in the uplands. The twentieth century saw a return to sheep and goat pastoralism for domestic use and subsistence ((Garde et al. 2014): 3). Depopulation increased the conversion of fields to hay production, which required less labour. During the summer, the animals of local villagers were combined with the transhumant animals to graze in the uplands. In the second half of the twentieth century, the whole agro-pastoral economy of the area contracted, progressively replaced by tourism complemented by long-distance transhumance ((Rosenberg 1988): 128-160), which remains the dominant pastoral strategy.

The highland meadows of Freissinières were increasingly abandoned between the late nineteenth and the early twentieth centuries, and significant areas of lowland fields were turned to forage production (ST2 - ADHA: 3 E 4465). The number of bovines and ovines did not increase between the nineteenth and the twentieth centuries, whereas the number of caprines rapidly dropped during this period (ST2 - ADHA: 3 E 4406). Although the high pastures were not completely abandoned by local herders/shepherds, the number of livestock from Provence summering in the uplands of Freissinières increased consistently during the twentieth century, largely outnumbering ovines and caprines of local origin (ST2 ADHA: W 2165966). Specialized dairy production never became established, and the milk produced by the farmers of
Freissinières was sold to the dairy of Briançon ((Baridon 1933): 57-63). These transformations had profound consequences for the local environment. Abros, in his synthesis of pastoral economies in the western Alps, cited Freissinières as an example of overexploitation of pasturelands triggered by overpopulation and unsuitable farming strategies during the mid-nineteenth century (1922: 218-220). Increasing depopulation led to the partial abandonment of the least accessible hamlets (like Dormillouse) during the midtwentieth century, subsequently to the progressive collapse of the local rural economy, and ultimately, the complete abandonment of high-meadows (ST 2 - ADHA: 3 E 4433). The incorporation of the high-altitudes of the valley into the Ecrins National Park during the 1970s, aimed at promoting sustainable land-use to mitigate the environmental impact of rural activities, led to the progressive transition towards a tourismdominated economy. However, long-distance transhumance remains and is important to the local economy.

\section{Upland Landscape Change}

Both the historical and modern cadastres of the Montagne de Faravel show that the area around the Fangeas lake and the alluvial fan of Les Balmettes are divided into small parcels belonging to different owners. This indicates that these two upland sectors were historically exploited as meadows, whereas the Faravel plateau and the adjacent area of Pont de Fer were probably used as common pastures. Today the entire Montagne de Faravel is used as common pasture during July and August (Fig. 1).

We recorded 87 historical structures in the Montagne de Faravel, including isolated huts, grouped huts and enclosures, and rockshelters (Fig. 2). One of these structures is currently used by the transhumant shepherd who rents the pastures of Faravel during the summer. We partially excavated four structures: one dated to the early medieval period, two to the latemedieval period, and one to the early-modern period (Mocci et al. 2006; Walsh 2005; Walsh and Mocci 2002). As expected, the structures dated to the Middle Ages are badly preserved, suggesting they have long been abandoned. The remaining 81 structures do not have a clear chronological attribution and show different levels of preservation. Interviews with retired farmers and herders, as well as local literary sources (Leroy and Baridon n.d.), enabled us to identify some of the structures that were still in use during the 1950s and 1960s: all of them are well preserved, and they retain part of the timber frame and posts used for the roof (Fig. 2, FR176). Ten structures were also identified in the 1834 cadastre, indicating that they were still exploited around the mid-nineteenth century. Yet some of the huts not recorded in the cadastre showed good preservation, with stone slabs (belonging to the roof cover) still leaning on the edge of the perimeter walls. Such remarkable preservation suggests that they might have 
been abandoned not long before the production of the cadastre, namely between the end of the eighteenth century and the first decades of the nineteenth century. These inferences, based on archaeological investigation, historical analysis, and preservation assessment, allowed us to create four broad chronological phases to describe the progressive abandonment of recorded structures (Table 1; see also Supplementary Table 1 ). We were able to approximately date 27 structures, but the period of abandonment was impossible to infer for the remaining 60 . This chronological analysis provides a useful dataset to evaluate the occurrence of temporal variations and spatial patterns in the abandonment of seasonal structures. A bar chart of the frequency of structures per chronological phase (Fig. 4) suggests that the most significant period of abandonment occurred during the early nineteenth century. Specific types of structures seem to have been abandoned in different periods: the compound structures (aggregated domestic and other functional units, like animal enclosures; Fig. 2, FR187) abandoned in Phase 2 (early 1800s) outnumber the huts abandoned in the same period; in Phase 3 (1850s-1950s), only isolated huts are abandoned whereas in Phase 4 (post-1950s) an equal number of isolated huts and compound structures were abandoned. GIS attribute queries (Conolly and Lake 2006): 112-122) and visual assessment of the resulting spatial distributions (Fig. 5) show how the buildings abandoned during the early nineteenth century and during the second half of the twentieth century were significantly clustered in two areas of the Montagne de Faravel: the former in the area of Pont de Fer, the latter around the Fangeas lake. Structures abandoned before the end of the eighteenth century or between the mid-nineteenth and midtwentieth century were scattered over the whole area, particularly in the common pastures of Faravel. However, the structures recorded in the meadows of Les Balmettes did not provide any reliable evidence of their abandonment phase.

These data suggest a significant abandonment of structures related to seasonal animal grazing (and possibly cheese production) just before the 1830 s, most of which were clustered in the area of Pont de Fer. Since the most recent possible exploitation of the mines of Faravel and Fangeas has been tentatively dated to the early nineteenth century (Ancel et al. 2007), it can also be argued that some of these structures might have been used by the miners working in the area. The most recent phase of abandonment, during the second half of the twentieth century, primarily concerns the huts around the Fangeas Lake. Historical cadastral and ethnographic information indicate that this area was used for winter fodder and the huts as temporary refuges for haymakers.

\section{Upland Environmental Change}

The palaeoecological evidence clearly demonstrates that the pastoral landscapes that characterised the post-medieval and modern periods have their origins in the Early Middle Ages. The highaltitude zones were exploited during the summer months and the highest levels of pastoral indicator species (Rumex, Plantago, etc.) date to the Late Middle Ages through to the late nineteenth and early twentieth centuries. In addition, mining activities, which require significant quantities of wood and timber, had an important impact on forest across all altitudes, and especially on the higher altitudinal zones that were most sensitive to human activities. Despite this, some high-altitude areas remained resilient, retaining stands of Larix/Picea, Pinus cembra, and Rhododendron and some Pinus sylvestris/ uncinata (Walsh et al. 2014). The palaeoenvironmental evidence from the region reflects the intersection of regional with wider economic networks. The extension and intensification of arboriculture, pastoralism, and mining provided goods for growing regional and national markets. Immediately to the west of Faravel, the bocage of the Champsaur area constitutes a complex human niche or set of niches that successfully combine a range of rural foodproduction activities within a sustainable ecological mosaic (Moustier 1996).

The underlying trend for the recent periods is the establishment of newly planted forest on the north-facing slopes of many valleys, the regeneration of natural forest (due to park management and climate change) and the contraction of pastoral (Rumex and Plantago) and arable indicator species. In addition, we have what must be a regional (inter-valley) signal for Olea. Within the Durance valley, reduction, and sometimes, disappearance, of certain economically significant plants, such as Cannabis, Secale, and Juglans, is particularly noteworthy. These changes reflect a move towards fruit arboriculture in parts of the region, as well as an emphasis on

Table 1 Abandonment phases of upland structures in Vallée de Frissinières, and their material and historical indicators

\begin{tabular}{|c|c|c|c|}
\hline Phase & Abandonment & Material indicators & Historical indicators \\
\hline Phase 1 & Before the end of the 18 th century & $\begin{array}{l}\text { Poorly preserved } \\
\text { Medieval/early-modern archaeological evidence }\end{array}$ & Not recorded in the 1834 cadastre \\
\hline Phase 2 & $\begin{array}{l}\text { Between the end of the } 18 \text { th and the } \\
\text { beginning of the 19th centuries }\end{array}$ & Stone slabs leaning on the edge of the walls & Not recorded in the 1834 cadastre \\
\hline Phase 3 & $\begin{array}{l}\text { Between the mid-19th century and the } \\
\text { mid-20th century }\end{array}$ & $\begin{array}{l}\text { Poorly preserved } \\
\text { Stone slabs leaning on the edge of the walls }\end{array}$ & Recorded in the 1834 cadastre \\
\hline Phase 4 & After the mid-20th century & *Timber posts/frames & *Identified by local informants \\
\hline
\end{tabular}



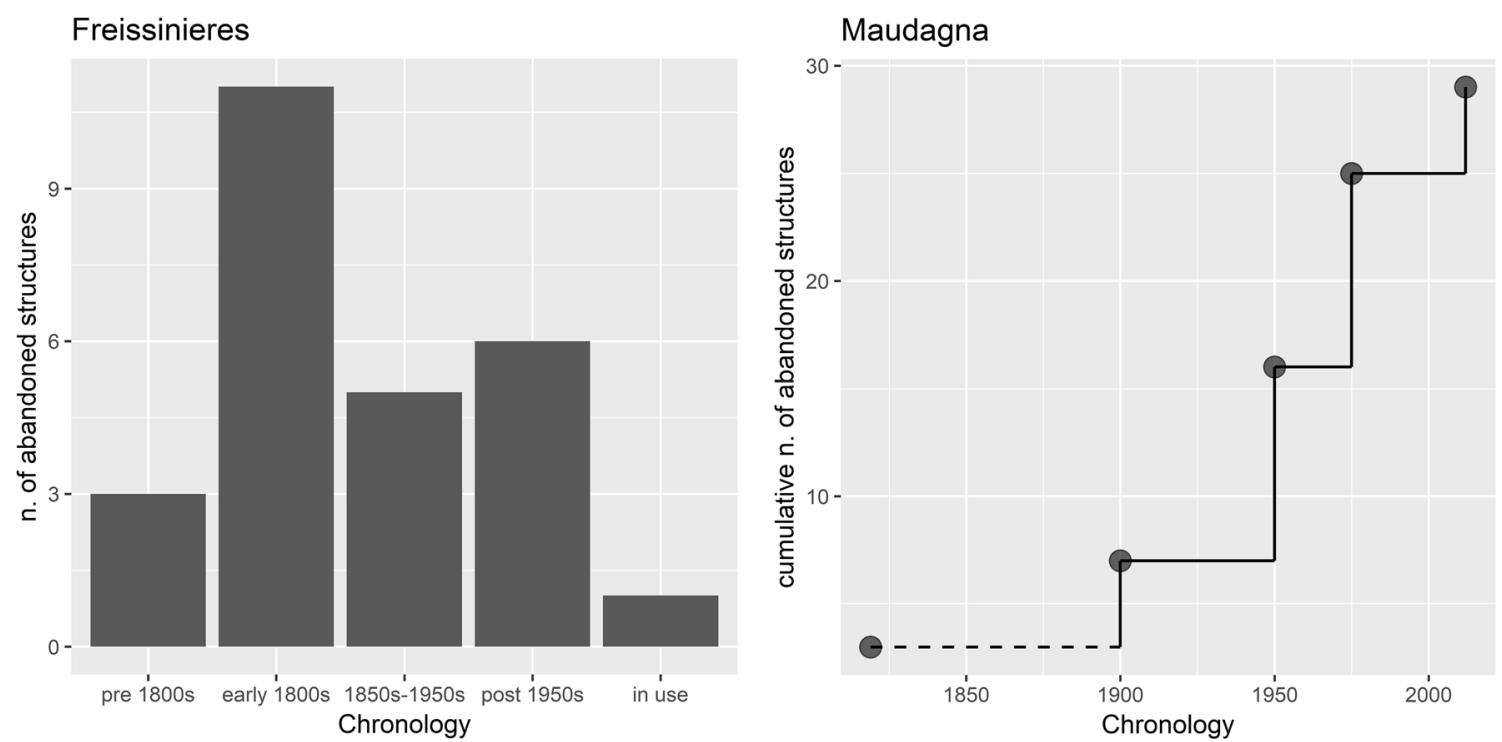

Fig. 4 Bar-chart of the number of abandoned structures in Vallée de Freissinières for each chronological phase (left); cumulative number of abandoned structures in Val Maudagna for each chronological phase (right)

animal fodder production along the Durance Valley bottom, and forestry along the abutting slopes. Again, these changes in the landscape trajectory reflect the influence of regional and national economic strategies, especially since the inception of the Common Agricultural Policy.

\section{Val Maudagna}

Val Maudagna is divided among different municipalities: Frabosa Sottana controls most of the valley bottom and most of the uplands, but a significant portion of these also belongs to Frabosa Soprana, Villanova Mondovì, and Magliano Alpi. Such an unusual administrative pattern originates from land redistributions at the end of the sixteenth century, when these municipalities were part of the commune of Mondoví (Mainardi 1979). For this reason, we surveyed the local archives of Frabosa Sottana and Mondoví to gather historical data on the human occupation of the uplands of Maudagna in the last three centuries (Supplementary Text 2 - ASFS, ASM).

We interviewed three retired male farmers and two retired male transhumant cattle-herders (marghé) that used to rent the
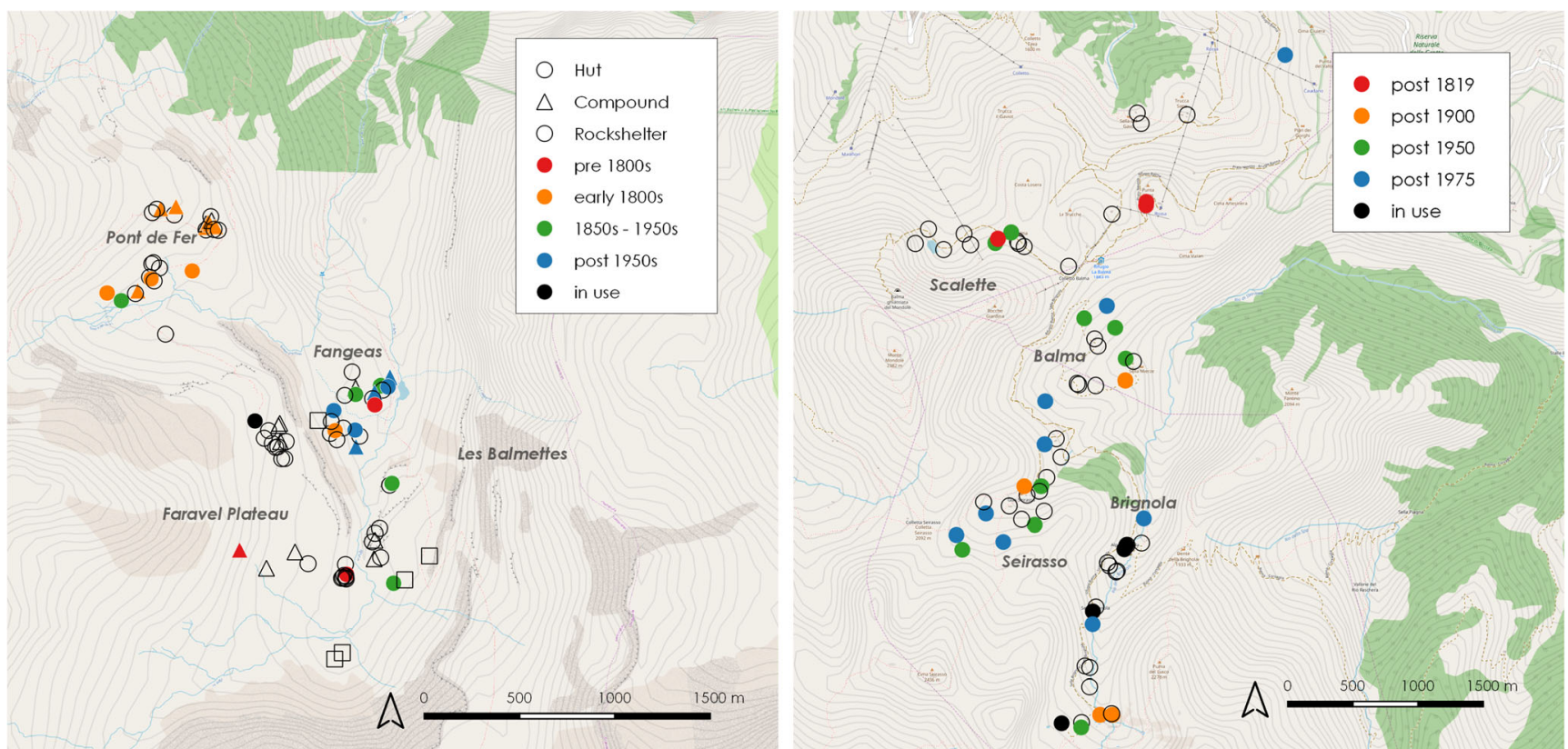

Fig. 5 Pastoral structures in the Vallée de Freissinières (left) and in Val Maudagna (right), characterised according to structure type and inferred chronology (undated structures are transparent). Background: Open Street Map 
upland meadows and pastures in Maudagna who provided useful information on the transformation of pastoral and farming strategies since the 1950s. We also interviewed four experienced marghé (two men and two women) that graze their livestock in the upland pastures of the valley about current pastoral practices, how these practices have been changing during the last decades, and how they expect these practices will develop in the future. Two policy makers, the mayor of Frabosa Sottana and the head of the veterinary office of Mondoví (responsible for the sanitary control of dairy and meat production in the study area) also provided feedback. The interviews were semi-structured, and the answers were audio-recorded and transcribed. A short period (10 days) of participant observation was also undertaken in the upland pastures with two experienced herders engaged in cattle breeding for meat production and goat breeding for cheese production.

Few archaeological surveys or palaeoecological analyses had been conducted in the study area prior to this research. During two fieldwork trips in 2013 and 2014, we recorded and studied the main landscape features in the uplands of Maudagna. We also surveyed and analysed standing pastoral structures recently abandoned by the local herders from an ethnoarchaeological point of view (Carrer 2017). For a detailed reconstruction of the historical ecology of the area, we relied on the palaeoenvironmental data provided by a peat-bog core from the neighbouring Val Ellero (Ortu et al. 2003), as well as on the retrogressive analysis of accurate historical maps available for the early nineteenth century (Cevasco and Poggi 1999).

\section{Upland Strategies Transformation}

The pastoral economy of Monregalese during the late eighteenth and early nineteenth century did not experience the same level of intensification described for the Briançonais. Investments seem to focus on the promotion of other activities, such as chestnut cultivation for tannin and marble quarrying. Farmers and cattle breeders from the neighbouring plain (marghé), as well as transhumant shepherds (bergé) seasonally occupied the high altitudes (Battaglini et al. 2012). They summered their livestock along with the animals of the local farmers and produced cheese (Rosso 1950). A transition from intensive to extensive use of the uplands occurred between the mid-nineteenth century (with the introduction of the new Forestry Code) and the mid-twentieth century, accelerated since the early twentieth century by depopulation and impoverishment of the local communities. These processes led to the progressive abandonment of upland hay-making, to the transformation of high-meadows into pastures, and to increasing deforestation of the mid- and high-altitudes to open new grazing areas (Cevasco and Poggi 1999). The second half of the twentieth century saw a partial contraction of cattleherding and dairy production (raschera cheese), which survived the generalized collapse of the rural economy.
Transhumance and sheep/goat-herding, instead, decreased from the 1930s and were almost absent from the area at the beginning of the twenty-first century. Winter tourism intensified in different valleys of the Monregalese from the 1960s. The EU regulation regarding cheese production (Council Regulation No 1255/1999 of 17 May 1999), applied since the early 2000s in the study area, contributed to the profound transformation of upland dairy strategies. Most of the traditional seasonal dairies were abandoned, replaced in some areas by modern structures complying with the legislation. Because of that, cattle-herders largely turned to meatfocused husbandry.

The economic history of Val Maudagna follows the general pattern outlined for the Monregalese. During the nineteenth century, cattle- and sheep-herding were crucial for the poor rural economy of Val Maudagna, and some management transformations and promotion initiatives were developed at the end of the century to increase production (ST2 - ASM: CAT 6 M. 2 Cart. 56). During the first half of the twentieth century, husbandry strategies in Val Maudagna were still domestic and largely related to small-scale subsistence economy. The under-exploitation of the pastures, partially related to difficulty of accessibility (ST2 - ASFS: c197), contributed to the emergence of shrubs that reduced the grazing surface (Ferro 1967), thus triggering a further contraction of pastoral activities. Changes in the cheese market and new EU regulations led to the development of lowland industrial dairies and to the progressive contraction of upland dairy during the last two decades.

\section{Upland Landscape Change}

The gias, traditional pastoral sites of the Ligurian and Maritime Alps, have been widely studied (e.g., (Mamino 2001; Roatta and Roatta 1999; Vecchiatini and Gnone 2015)). They are composed of one or two small dry-stone huts (casot), with a removable roof, and often located in a flat and sheltered area, suitable for the animals to stay overnight. Until the end of the twentieth century, most were still used for milk processing and dairy production, and some are close to masonry cellars (celle) where cheese was stored and matured (ST2 - ASFS: c198, c701; ST2 - ASM: CAT 6 M. 1 Cart. 48, CAT 6 M. 2 Cart 45). We recorded 49 gias during three fieldwork trips to the pastures of Val Maudagna (Fig. 3), four of which had been in use until 2012. We conducted archaeological investigations in one, thus enabling a chronological attribution to the sixteenth-seventeenth century (Carrer 2015). For the other structures, the period of use and abandonment can be inferred using ethnographic information and documentary sources, and evaluating their state of preservation. The earliest historical evidence of gias in Val Maudagna dates back to the early nineteenth century (ST2 - ASFS: r42), but the earliest map that shows the location of traditional casot is the 
"Carta degli Stati Sardi di Terraferma" (1852, 1:50,000), resulting from a survey undertaken in 1818 and 1819 (Archivio di Stato di Torino, Italy). Six of the casot recorded in the field were identified in this map. Sporadic surface finds facilitated the identification of the last period of occupation for some structures, whereas timber posts still preserved suggested the relatively recent abandonment of others. A number of casot were also characterised by remains of corrugated sheeting used for the roof. Local informants indicated corrugated sheeting being used since the 1950s, thus providing a reliable terminus post quem for the abandonment of these huts. Similarly, the use of mortar to consolidate the walls of the casot (Fig. 3, FB058) and the use of nylon fabric to insulate the roof and the walls are documented since the second half of the twentieth century. Therefore, casot with mortar walls and/or traces of nylon fabric are supposed to have been abandoned during the late twentieth century. Furthermore, in the second half of the twentieth century, some dry-stone structures were replaced by prefabricated cabins (Fig. 3, FB065), which were in turn abandoned when the local authorities built modern dwellings and seasonal dairies at the beginning of the twenty-first century (Fig. 3, FB005). This complex chronological information enabled us to create five phases of abandonment for the pastoral sites in Val Maudagna (Table 2). Twentynine of the 49 structures were attributed to one of these categories (Supplementary Table 2). The phases created for Val Maudagna suggest the earliest possible period of abandonment. For example, a structure in Phase 2 could have been abandoned any time between the beginning and the end of the twentieth century. For this reason, the most suitable way to analyse and visualise these data is using the cumulative frequency distribution, thus representing the maximum number of structures that could have been abandoned in each period. The observed cumulative frequency enables identification of discontinuities in the abdandonment process (Fig. 4). The cumulative distribution plot highlights that the abandonment rate rapidly increased during the second half of the twentieth century (Phase 3 and 4), and the apparent decrease in the last decades (Phase 5) is simply related to the fact that only four gias were still in use until the early 2010s. The mid-twentieth century seems to have been a tipping point in the evolution of the upland landscapes of Val Maudagna. On the other hand, site distribution does not suggest any clear spatial pattern of abandonment (Fig. 5), and only the four gias still in use in the 2000s were aggregated in a single area (the pasture of Brignola).

\section{Upland Environment Change}

Pollen analysis from a peat-bog core near Rifugio Mondoví (1760 $\mathrm{m}$ asl) in the neighbouring Val Ellero (Ortu et al. 2003), showed that the upland environment in this area of the Maritime Alps has been influenced by human activity since prehistoric times, and culminated with the increasing cultivation of chestnut during the medieval and post-medieval periods. Cartographic regression enables a more detailed investigation of the ecological changes occurred during the last two centuries (Cevasco and Poggi 1999). Here the integrated use of high-altitudes for silviculture, haymaking, and seasonal pastoralism was progressively replaced by a sparse and lowintensity pastoral exploitation between the mid-nineteenth and the mid-twentieth centuries. This development had profound environmental consequences: from the expansion of woodlands to the densification of alder forest to the decline of water management in the high pastures.

Interviews with local stakeholders and policy makers provided information on the environmental change occurring in the last decades. The abandonment of the highest pastures, mainly related to a significant decrease in sheep-herding, led to the spread of shrubs and conifers, thus to the shrinking of grazing areas. The most remote sectors of the uplands, isolated and impossible to reach with motorised vehicles, are also largely abandoned or underexploited by cattle herders, and therefore subjected to increasing reforestation. The decreasing surface of open pastures intersects with another phenomenon of pasture degradation triggered by land-use change. According to local herders, the gias were rotated every summer, and it was rare that the same gias was used twice in two

Table 2 Abandonment phases of the upland structures in Val Maudagna, and their material and historical indicators

\begin{tabular}{|c|c|c|c|}
\hline Phase & Abandonment & Material indicators & Historical indicators \\
\hline Phase 1 & After 1819 & 19th-century material culture & Documented in the 1818-1819 map \\
\hline Phase 2 & After the beginning of the 20th century & $\begin{array}{l}\text { Timber posts } \\
\text { Early 20th-century material culture }\end{array}$ & \\
\hline Phase 3 & After the mid-20th century & $\begin{array}{l}\text { Metal sheet } \\
\text { 2nd half of the 20th-century material culture }\end{array}$ & Ethnographic information \\
\hline Phase 4 & After the third quarter of the 20th century & $\begin{array}{l}\text { Concrete } \\
\text { Nylon fabric } \\
\text { Late } 20 \text { th - early } 21 \text { st centuries material culture }\end{array}$ & Ethnographic information \\
\hline Phase 5 & After the first decade of the 21 st century & Remarkable preservation & Ethnographic information \\
\hline
\end{tabular}


consecutive years. This strategy favoured uniform exploitation and manuring of the pasture, thus preserving or improving the quality of the grass. However, in the current system grazing activity clusters around a few seasonal dairies or pastoral huts. As a consequence, the areas immediately surrounding these structures are overexploited and increasingly affected by erosion, whereas the grazing areas next to them are overmanured and rich in nitrophilous plants. The increasing ecological footprint of pastoral practices as a consequence of intensive grazing in limited sectors of the uplands, suggests that the developments of seasonal activities in the last decades had an impact on the size, quality and biodiversity of mountain pastures in Val Maudagna.

\section{Discussion}

According to the available historical sources, the use of upland pastures in the two study areas during the late-medieval and post-medieval periods showed significant similarities. Local communities were summering cattle, sheep, and goats at highaltitudes to produce cheese for subsistence and small markets. The landscape was characterised by common grazing areas dotted with small dwellings and dairies (chalets d'alpage in the Briançonais, gias in the Monregalese) and by privately managed meadows that provided fodder for winter stabling. The key rupture occurred with the French revolution, which radically changed the organisation of many aspects of the rural economy (Jussiau et al. 1999).

The post-revolutionary (end of the eighteenth - beginning of the nineteenth centuries) consolidation of power and reorganisation of local administration contributed to the separation of the economic strategies on the two sides of the Western Alps, triggering the differentiation of upland landscape trajectories. In order to mitigate the contraction of the wool trade, French policy makers fostered the development of cheese-production, focused on large collective dairies. The abandonment of compound structures in the sector of Montagne de Faravel known as Pont de Fer is attributed to this chronological period and suggests a decreasing intensity in pastoral activities in this phase. However, palaeoecological data do not show any significant decrease in pastoral markers, and this can be attributed to the presence of transhumant shepherds from Provence, which significantly increased from the beginning of the nineteenth century. In the same period, the economic investments in the Monregalese were aimed at opening and managing marble quarries and exploiting tannin from chestnut trees for the growing chemical industry. Animal husbandry and cheese production remained secondary and still focused on subsistence and small markets. Therefore, summer farming continued almost unchanged until the midnineteenth century, as suggested by local documentary sources and the persistence of the gias system (archaeologically documented in Val Maudagna).

The nineteenth century was characterised in both areas by growing demographic pressure and by the development of the Forestry Code, which affected small-scale farming activities everywhere in the Alps (Simon et al. 2007). The different trajectories of the Briançonais and Monregalese economies influenced the adaptation to these changes: decreasing pressure on the uplands coupled with increasing pressure on lowland fields and meadows in the former, and the progressive shift from an intensive to extensive use of the uplands in the latter. These transformations, in turn, had profound consequences on the upland landscapes. In the Montagne de Faravel numerous isolated huts were abandoned after the mid-nineteenth century, suggesting a decline not only in the use of common pasturelands, as seen during the previous period, but also and most importantly in the exploitation of high meadows. The decline of haymaking in the uplands characterises Val Maudagna as well, and led to the conversion of meadows into grazing areas and in the partial abandonment of the highest and least accessible pastures. This, in turn, might have produced an expansion of gias, as seems to be suggested by the fact that many of those recorded during fieldwork are not included in the early nineteenth century maps.

A significant discontinuity in the history of upland landscapes is represented by the 1950s and 1960s. A large number of compound structures and isolated huts were abandoned in this phase in the Montagne de Faravel and the abandonment of gias in the pastures of Val Maudagna also shows an abrupt increase. This acceleration corresponds to the crisis of the traditional rural economy, documented not only in the studyareas or in the Alps but also in many parts of Europe in the same period (Collantes and Pinilla 2011). Permanent migrations, triggered by unsustainable demographic pressure and macro-economic processes, loosened social bonds and affected available labour, thus increasing costs and yields of smallscale farming. With the definitive collapse of dairy-focused cattle husbandry in the Vallée de Freissinières, the demand for fodder rapidly dropped, and the upland meadows were the first to be abandoned. Distribution maps show that most of the recently abandoned huts cluster around the Fangeas Lake, an area that was used for summer fodder until the 1960s. Historical cadastres show that the neighbouring area of Les Balmettes was exploited for the same purpose, but it has turned into common pasture in recent times. Although a chronology of abandonment could not be suggested for the structures scattered in this area, it can be reasonably argued that this significant functional change came to a conclusion by the second half of the twentieth century. The less intensive use of the uplands, increasingly rented to transhumant shepherds from Provence, is also visible in the palaeoecological record, which shows a remarkable decrease in indicators of pastoral 
activities and evidence of reforestation. Between the 1950s and the 1970s most of the gias in Val Maudagna were abandoned due to the contraction of pastoralism and in particular of dairy-focused pastoralism. Our archaeological investigations suggest cattle-herders (marghé) who continued to summer animals in the high-mountains and produce cheese were still using the gias as they had been used in previous centuries.

The end of the twentieth century shows a continuation of the slow processes started in the 1950s for the Vallée de Freissinières, whereas new European regulations had profound consequences for local economy and upland landscapes in Val Maudagna. Since the 1970s the Montagne de Faravel has been part of the National Parc des Ecrins, which has contributed to conserve and promote pastoral uses of this area. Currently, the pastures of Faravel are exploited by transhumant shepherds from Provence and there is only one nonephemeral structure still in use in the whole area: la grande cabane de Faravel (the big hut of Faravel), which was documented in the historical cadastre. However, the uplands are once more at the centre of the economy of the valley, as they are visited by thousands of tourists every year. In Val Maudagna, EU legislation for dairy production, implemented in Italy since the early 2000s, led to the abandonment of the few gias still occupied. Some new dairies complying with the new legislation were built, but most of the cattle herders turned to meat production.

\section{Conclusions}

The detailed analysis of the history of upland landscapes in two sectors of the Western Alps shows how socioeconomic idiosyncrasies affected the evolution of seasonally exploited landscapes. This contributes to our rejection of the simplistic interpretation of socio-ecological dynamics at high altitude as exclusively adaptive and stable over time and that functioned in isolation from wider regional and supra-regional economic and political processes. Three main conclusions can be drawn from our data and inferences presented above.

\section{Drivers of Change in Upland Landscapes}

The historical changes recorded in the upland landscapes of Freissinières and Maudagna were triggered by economic and political shifts, some of which have been recognised as drivers of change in other European landscapes (Bürgi et al. 2017). Transformations in upland landscapes do not seem to be linearly correlated to climatic or demographic fluctuations, as suggested by the increasing intensity of human activity during the last phase of the Little Ice Age (eighteenth century and first half of the nineteenth century) (Painter et al. 2013). This leads us to the conclusion that upland landscapes are by no means different from other types of European landscapes, and recognizing the driving forces that contributed to shaping their historical character (Bürgi et al. 2004; Turner 2007) can inform their future management (Antrop 2005).

Since the end of the eighteenth century, the economic strategies on the French and Italian sides of Maritime Alps significantly diverged, and environmental knowledge in Val Maudagna and Vallée de Freissinières evolved in the face of changing socioeconomic configurations. This led to different evolutionary paths for the upland landscapes of the two studyareas, which contributed to shaping their current distinct characters. Therefore, whilst we accept that the environment provides a limited set of options at high altitude, what people do in (and to) these landscapes is not necessarily constrained by these environmental characteristics, but is a set of responses to complex arrays of ecological, economic, cultural stimuli. Analysing these responses and their implications for landscape change is necessary to design future development policies (Fonderflick et al. 2010; Perlik 2019).

\section{Sustainability and Resilience of Traditional and Current Practices}

Recent transformations in upland landscape management are often regarded as negative compared to pre-modern practices, and associated to the loss of resilience, ecological sustainability, and ecological knowledge (Fischer et al. 2008; Gretter et al. 2018; Pecher et al. 2017; Schirpke et al. 2013). However, this argument needs to be assessed for the different areas and periods investigated rather than assumed a priori. Our two study-areas, for instance, provide contrasting perspectives.

On the one hand, the ongoing transformations of seasonal practices in Val Maudagna, with the progressive decline of pastoral activities during the twentieth century, are clearly producing a depletion of pasture quality and incremental soil-loss (the shrinking of grazing areas and change in locational strategies enhance the detrimental effects of manuring and livestock trampling). The example of Val Maudagna aligns with the general narrative suggesting modern economic strategies are the main drivers of decreasing landscape quality, especially in mountain regions (Previtali 2011). On the other hand, the uplands of Vallée de Freissinières were overexploited in the nineteenth century, with a large impact of deforestation (associated with pasture, arable farming, and mining) and serious problems with flooding and erosion. The progressive abandonment of the valley in the twentieth century did not prove beneficial for the ecosystem either, as it led to intensive exploitation of some sectors and reforestation of others (decreasing plant biodiversity). This scenario is in stark contrast to the management strategies developed during the second half of the twentieth century. Twenty years after World War II, different national parks were created in France: the Parc National des Ecrins, including the uplands of 
Freissinières, was created in 1972. National parks contributed to monitoring (through park wardens) advantages and disadvantages of traditional practices like the use of fire in landscape management, and ultimately promoted a more sustainable development of upland farming ((Larrère et al. 2009): 19). In the case of Freissinières, local adaptation to changing socioeconomic conditions was particularly difficult in the transition to modernity, and only a recent State intervention (the creation of National Parks) provided a management solution for fostering ecosystem conservation. If it is clear that this solution did not contribute to local-community resilience (most of the people living in the valley and the shepherds working in the uplands depend on the existence of the Park), it must be acknowledged that it addressed some of the preexisting issues of landscape management.

These divergences between Maudagna and Freissinières depend on their different historical evolution. Similar localscale pastoral strategies were carried out in the two valleys in the eighteenth century, but the low economic importance of pastoralism in Maudagna slowed down its transformation until the mid-twentieth century, thus favouring the longer persistence of less intensive and more resilient seasonal farming practices. Conversely, early investments in dairy produce in France led to significant transformations of pastoral economies in the French Alps, and to the aforementioned consequences for landscape and ecosystems in Fressinières. Therefore, what is understood as the result of a long-term adaptation to the upland environment is probably just the consequence of a more marginal economic role of pastoralism in specific areas and periods. During the transition to modernity, a higher strategic relevance of upland rural strategies might have determined lower ecological sustainability and lower resilience for mountain communities. Our analysis highlights the complex correlation between the historical development of seasonal farming and the evolution of its ecological impact, and suggests that long-term perspectives are critical to reliably assess the sustainability of rural practices (Bennett et al. 2015).

\section{Challenging the Concept of 'Traditional' Land-Management}

The clear relationship between socioeconomic processes and the development of sustainable or unsustainable upland landscape management leads us to question the key concept of 'traditional' practices and ecological knowledge. According to our research, the influence of economic and political trends on seasonal farming strategies largely predates the twentieth century, and significant changes have been recorded for the entire investigated period. Although the generalised collapse of the rural economy in the 1950s and 1960s represents a critical upheaval for the rapid evolution of upland practices and landscapes it was preceded by other equally influential historical processes during the eighteenth and nineteenth centuries. Sustainability studies in different mountain regions suggest that traditional ecological knowledge is eroded by the integration of small-scale societies in the market economy, with negative consequences for the provision of ecosystem services ((Grêt-Regamey et al. 2008; Huber et al. 2013; MacDonald et al. 2000; Rescia et al. 2008)). However, rural communities in the Alps have been fully integrated into wide economical networks for several centuries (Rosenberg 1988; Mathieu 2009), and this study demonstrates that humanenvironment interaction at high altitude has been deeply influenced by these networks. If traditional upland practices are perceived as the product of local adaptation to alpine/ subalpine zones of mountain ecosystems and are assumed to be unchanged for centuries (Fernández-Giménez and Fillat Estaque 2012; Maurer et al. 2006), the eighteenth- and nineteenth-century high-mountain strategies investigated in Maudagna and Freissinières cannot properly be considered traditional. Besides, although dearth of historical sources and the difficult interpretation of ephemeral archaeological evidence prevents the detailed analysis of upland farming practices and upland landscape change in earlier historical or prehistoric periods, it can be argued that exogenous socioeconomic processes influenced mountain socio-ecological systems long before the early modern period (Carrer and Angelucci 2018), and possibly since prehistoric times.

\section{Final Remarks}

These conclusions show that a more accurate historical perspective is necessary to improve our understanding of mountain landscapes and promote sustainable and resilient development strategies for the future. The current unilinear evolutionary approach, which assumes a correlation between upland traditional practice and sustainable land-use, must be calibrated with a detailed assessment of the long-term transformation in human interaction with upland environments. This requires mountain communities should not be analysed in isolation, but as nodes of larger social, political, and economic frameworks, which shape local strategies of adaptation to upland ecosystems. Sustainability and resilience, rather than being a natural inclination of small-scale societies (depleted by industrialisation and globalisation in the last 50 years) become the product of complex historical dynamics, which explain their positive and negative fluctuation in different historical periods (Mathieu 2011). Acknowledging the non-linearity of the evolution of farming practices and ecological knowledge would significantly influence the identification of future landscape change trajectories and the usefulness of the "lessons from the past" in landscape management policy. 
Acknowledgments We are extremely grateful to all the people who helped us during fieldwork, in particular Giovanni Comino, Gian Piero Rinaudo (ASL CN1, Mondovi), Richard Bonet and the other colleagues of the Parc National des Ecrins. We are also grateful to the two anonymous reviewers for their useful comments and suggestions. Special thanks to Stefano Biagetti for reviewing the first draft of this paper.

Funding Information This work was supported by the 7th EU framework Marie Curie Intra-European Fellowship (FP7-PEOPLE-2012-IEF).

\section{Compliance with Ethical Standards}

All the participants in the ethnographic and ethnoarchaeological work have been given an information sheet about the project (in their native language) and asked to provide informed consent in writing. Research was approved by the University of York in compliance with the European code of research integrity.

Conflict of Interest The authors declare that they have no conflict of interest.

Open Access This article is licensed under a Creative Commons Attribution 4.0 International License, which permits use, sharing, adaptation, distribution and reproduction in any medium or format, as long as you give appropriate credit to the original author(s) and the source, provide a link to the Creative Commons licence, and indicate if changes were made. The images or other third party material in this article are included in the article's Creative Commons licence, unless indicated otherwise in a credit line to the material. If material is not included in the article's Creative Commons licence and your intended use is not permitted by statutory regulation or exceeds the permitted use, you will need to obtain permission directly from the copyright holder. To view a copy of this licence, visit http://creativecommons.org/licenses/by/4.0/.

\section{References}

Acovitsioti-Hameau A (2015) De la châtaigne l'hiver et du fromage l'été. Productions vivrières, aliments ordinaires et identité locale dans la haute vallée d'Arroscia. In: Moscatelli U and Stagno AM (eds.) Archeologia delle Aree Montane Europee: Metodi, Problemi e Casi di Studio. Il Capitale Culturale. Macerata: University of Macerata, pp. 637-662.

Alther, Y (2014) Vertikal Mobil. Ein Beitrag Zum Verständnis Alpiner Wirtschaftsformen in Der Archäologie. Sonderheft. Archäologie Grabünden

Ancel B, Py V and Burri S (2007) Freissinières - Les mines métalliques de Faravel et de Fangeas. ADLFI. Archéologie de la France Informations. une revue Gallia. USR 3225 MAE René-Ginouvès. Available at: http://journals.openedition.org/adlfi/6588 (accessed 20 September 2019).

Antrop, M. (2005). Why landscapes of the past are important for the future. Landscape and Urban Planning 70: 21-34.

Arbos P (1922) La Vie Pastorale Dans Les Alpes Françaises. Étude de Géographie Humaine. Paris: Librairie Armand Colin.

Balée, W. (1998). Introduction. In Balée, W. (ed.), Advances in Historical Ecology, Columbia University Press, New York, pp. 1-10.

Baridon F (1933) Le Val de Freissinieres.

Battaglini L, Verona M and Corti M (2012) Sostenibilità dell'allevamento pastorale in Piemonte: Primi risultati di un progetto finalizzato. In: Varotto M and Castiglioni B (eds.) Di Chi Sono le Alpi? Appartenenze Politiche, Economiche e Culturali nel Mondo
Alpino Contemporaneo. Padova: Padova University Press, pp. 132-41.

Bennett, E. M., Cramer, W., Begossi, A., et al (2015). Linking biodiversity, ecosystem services, and human well-being: Three challenges for designing research for sustainability. Current Opinion in Environmental Sustainability 14: 76-85.

Braudel F (1949) La Méditerranée et Le Monde Méditerranéen à L'époque de Philippe II. Paris: Armand Colin.

Bürgi, M., Hersperger, A. M., and Schneeberger, N. (2004). Driving forces of landscape change - current and new directions. Landscape Ecology 19: 857-868.

Bürgi, M., Bieling, C., von Hackwitz, K., et al (2017). Processes and driving forces in changing cultural landscapes across Europe. Landscape Ecology 32(11): 2097-2112.

Carrer, F. (2015). Magliano Alpi, Località Sella Brignola. Indagine archeologica di una struttura pastorale tradizionale in alta quota. Quaderni Della Soprintendenza Archeologica Del Piemonte 30: 326-329.

Carrer, F. (2017). Interpreting intra-site spatial patterns in seasonal contexts: An Ethnoarchaeological case-study from the Western Alps. Journal of Archaeological Method and Theory 24: 303-327.

Carrer, F., and Angelucci, D. E. (2018). Continuity and Discontinuity in the History of Upland Pastoral Landscapes: The Case Study of Val Molinac and Val Poré (Val Di Sole, Trentino, Eastern Italian Alps). Landscape Research 43(6): 862-877.

Cevasco R and Poggi G (1999) Per una definizione storica del patrimonio rurale delle valli Monregalesi: alpeggi della 'raschera.' In: Galante Garrone G, Griseri A, Lombardini S, et al. (eds.) Le Risorse Culturali delle Valli Monregalesi e la Loro Storia. Comunità Montana Valli Monregalesi, pp. 9-29.

Christie, N., Beavitt, P., Santonja, J. G., et al (2007). Peopling the recent past in the Serra de L'Altmirant: Shepherds and farmers at the margins. International Journal of Historical Archaeology 11(4): 304 321.

Collantes, F., and Pinilla, V. (2011). Peaceful Surrender: The Depopulation of Rural Spain in the Twentieth Century, Cambridge Scholars Publishing, Newcastle upon Tyne.

Conolly J and Lake M (2006) . Cambridge: Cambridge University Press.

David, N., and Kramer, C. (2001). Ethnoarchaeology in Action, Cambridge University Press, Cambridge.

Eriksson, C. (2011). What is traditional pastoral farming? The politics of heritage and 'real values' in Swedish summer farms (fäbodbruk). Pastoralism: Research, Policy and Practice 1: 25. https://doi.org/10. 1186/2041-7136-1-25.

Fernández-Giménez, M. E., and Fillat Estaque, F. (2012). Pyrenean pastoralists' ecological knowledge: Documentation and application to natural resource management and adaptation. Human Ecology 40(2): $1-14$

Ferro, G. (1967). Ricerche di Geografia Umana nelle Valli del Monregalese. Rivista Geografica Italiana 74(1).

Festi, D., Putzer, A., and Oeggl, K. (2014). Mid and Late Holocene landuse changes in the Ötztal Alps, territory of the Neolithic iceman 'Ötzi'. Quaternary International 353: 17-33.

Fischer, M., Rudmann-Maurer, K., Weyand, A., et al (2008). Agricultural land use and biodiversity in the Alps. Mountain Research and Development 28(2): 148-155.

Fonderflick, J., Lepart, J., Caplat, P., et al (2010). Managing agricultural change for biodiversity conservation in a Mediterranean upland. Biological Conservation 143: 737-746.

Garde, L., Dimanche, M. and Lasseur, J. (2014). Permanence and changes in pastoral farming in the southern Alps. Journal of Alpine Research 102(2). https://doi.org/10.4000/rga.2416.

Granet-Abisset A-M (1997) La Mobilité: Trait Majeur de Comportement Des Sociétés Alpines. In: Duclos J-C (eds.) Village D'altitude. Connaitre ;e Patrimoine, Servir le Développement. Actes Du 
Séminaire Des 7 et 8 Décembre 1995. Centre Des Esquirousses Arvieux - Hautes-Alpes. Turriers: Transfaire, pp. 87-98.

Grêt-Regamey, A., Walz, A., and Bebi, P. (2008). Valuing ecosystem Services for Sustainable Landscape Planning in Alpine regions. Mountain Research and Development 28(2): 156-165.

Gretter, A., Ciolli, M., and Scolozzi, R. (2018). Governing Mountain landscapes collectively: Local responses to emerging challenges within a systems thinking perspective. Landscape Research 43(8): $1117-1130$

Guichonnet P (ed.) (1980) Histoire et Civilisations Des Alpes. Tourlouse, Lausanne.

Huber, R., Rigling, A., Bebi, P., et al (2013). Sustainable land use in mountain regions under global change: Synthesis across scales and disciplines. Ecology and Society 18(3): 36. https://doi.org/10.5751/ es-05499-180336.

Johnson, J. T., Howitt, R., Cajete, G., et al (2016). Weaving indigenous and sustainability sciences to diversify our methods. Sustainability Science 11(1): 1-11.

Jussiau R, Montméas L and Parot J-C (1999) L'élevage en France: 10 000 ans d'histoire. Educagri Editions.

Laland, K. N., and O'Brien, M. J. (2010). Niche Construction Theory and Archaeology. Journal of Archaeological Method and Theory 17(4): 303-322.

Larrère R, Lizet B and Berlan-Darqué M (2009) Histoire des parcs nationaux: Comment prendre soin de la nature? Editions Quae.

Leroy Y, and Baridon H (n.d.) Abris Jadis Utilisés Par Les Habitants de Freissinières et Aujourd'hui Utilisables Par Les Randonneurs. Paris: RDV Copie.

MacDonald, D., Crabtree, J. R., Wiesinger, G., et al (2000). Agricultural abandonment in mountain areas of Europe: Environmental consequences and policy response. Journal of Environmental Management 59(1): 47-69.

Mainardi A (1979) Vecchia Frabosa. Storia di gente venuta dal monte che sul monte ha vissuto, sofferto e sperato. Frabosa Sottana $(\mathrm{CN})$ : Comune di Frabosa Sottana.

Mamino L (ed.) (2001) Atlante dell'Edilizia Montana nelle Alte Valli del Cuneese. 1: le Valli Monregalesi (Valli Casotto, Corsaglia, Maudagna, Ellero). Mondovì: Politecnico di Torino.

Marini, L., Klimek, S., and Battisti, A. (2011). Mitigating the impacts of the decline of traditional farming on mountain landscapes and biodiversity: A case study in the European Alps. Environmental Science \& Policy 14: 258-267.

Mathieu J (2009) History of the Alps, 1500-1900: Environment, Development, and Society. Morgantown: West Virginia University Press.

Mathieu J (2011) The Third Dimension: A Comparative History of Mountains in the Modern Era. White Horse Press.

Maurer, K., Weyand, A., Fischer, M., et al (2006). Old cultural traditions, in addition to land use and topography, are shaping plant diversity of grasslands in the Alps. Biological Conservation 130(3): 438-446.

Mientjes, A. C. (2004). Modern pastoral landscapes on the island of Sardinia (Italy). Recent pastoral practices in local versus macroeconomic and macro-political contexts. Archaeological Dialogues 10(2): 161-190.

Mocci F, Tzortzis S, Palet-Martinez J-M, et al. (2006) Peuplement, Pastoralisme et Modes d'Exploitation de La Moyenne et Haute Montagne Depuis la Préhistoire dans le Parc National des Ecrins (vallées du Haut Champsaur et de Freissinières, Hautes-Alpes). In: Bouet A and Verdin FI (eds.) Territoire et Paysages de L'âge Du Fer Au Moyen-Age, Mélanges Offerts Philippe Leveau. Bourdeaux: Université de Bourdeaux, pp. 197-212.

Moustier, P. (1996). Le Bocage Champsaurin. Méditerranée 83: 37.
Netting RM (1981) Balancing on an Alp: Ecological Change and Continuity in a Swiss Mountain Community. Cambridge: Cambridge University Press.

Ortu, E., David, F., and Caramiello, R. (2003). Rôle de L'homme Dans L'histoire de La Végétation de La Vallée Ellero (Alpes Maritimes, Italie). Comptes Rendus Biologies 326: 631-637.

Oteros-Rozas, E., Ontillera-Sánchez, R., Sanosa, P., et al (2013). Traditional ecological knowledge among transhumant pastoralists in Mediterranean Spain. Ecology and Society 18(3): 33.

Painter, T. H., Flanner, M. G., Kaser, G., et al (2013). End of the little ice age in the alps forced by industrial black carbon. Proceedings of the National Academy of Sciences of the United States of America 110(38): 15216-15221.

Pecher, C., Bacher, M., Tasser, E., et al (2017). Agricultural landscapes between intensification and abandonment: The expectations of the public in a Central-Alpine cross-border region. Landscape Research 43(3): 428-442.

Perlik, M. (2019). The spatial and economic transformation of mountain regions. Routledge.

Plieninger, T., Höchtl, F., and Spek, T. (2006). Traditional land-use and nature conservation in European rural landscapes. Environmental Science \& Policy 9(4): 317-321.

Pluciennik, M., Mientjes, A., and Giannitrapani, E. (2004). Archaeologies of aspiration: Historical archaeology in rural Central Sicily. International Journal of Historical Archaeology 8(1): 27-65.

Previtali, F. (2011). Mountain Anthroposcapes, the Case of the Italian Alps. In: Kapur, Eswaran S, and Hari (eds.) Sustainable Land Management: Learning from the Past for the Future. Springer, Heidelberg, pp. 143-61.

Rescia, A. J., Pons, A., Lomba, I., et al (2008). Reformulating the socialecological system in a cultural Rural Mountain landscape in the Picos de Europa region (northern Spain). Landscape and Urban Planning 88: 23-33.

Roatta, M. and Roatta, M. (1999). Gli Edifici per l'Abitazione e il Lavoro. Tipologia, Insediamenti, Tecnologia e Materiali. In: Galante Garrone G, Griseri A, et al. (eds.) Le Risorse Culturali Delle Valli Monregalesi e la loro Storia. Comunità Montana Valli Monregalesi.

Rosenberg, H. G. (1988). A Negotiated World: Three Centuries of Change in a French Alpine Community, University of Toronto Press, Toronto.

Rosso, G. (1950). Vita Economica, Insediamento Stagionale, Tipi di Abitazione nelle Valli Superiori del Pesio e dell'Ellero nell'Alto Monregalese. Atti dell'Accademia Ligure di Scienze e Lettere VII(1).

Scaramellini, G., and Varotto, M. (eds.) (2008). Terraced Landscapes of the Alps, Atlas, Marsilio, Venice.

Schirpke, U., Leitinger, G., Tasser, E., et al (2013). Multiple ecosystem Services of a Changing Alpine Landscape: Past, present and future. International Journal of Biodiversity Science, Ecosystems Services \& Management 9(2): 123-135.

Simon, L., Clément, V., and Pech, P. (2007). Forestry disputes in provincial France during the nineteenth century: The case of the Montagne de lure. Journal of Historical Geography 33: 335-351.

Skibo, J. M. (2009). Archaeological theory and Snake-oil peddling. The role of Ethnoarchaeology in archaeology. Ethnoarchaeology 1(1): $27-56$.

Turner, S. (2007). Landscape archaeology for the past and future: The place of historic landscape characterisation. Landscapes 8(2): 40 49.

Vecchiatini, R., and Gnone, M. (2015). Costruzioni e Paesaggi d'Alpeggio delle Alpi Liguri: Conoscenza per una tutela possibile. Il Capitale Culturale 12: 663-688. 
Viazzo, P. P. (1989). Upland Communities: Environment, Population and Social Structure in the Alps since the Sixteenth Century, Cambridge University Press, Cambridge.

Vivier, N. (1992). Le Briançonnais Rural Aux XVIIIe et XIXe Siècles. Paris: L'Harmattan.

Walker, B., Holling, C. S., Carpenter, S. R., et al (2004). Resilience, adaptability and transformability in social-ecological systems. Ecology and Society 9(2): 5.

Wallerstein, I. (2011). The Modern World-System I: Capitalist Agriculture and the Origins of the European World-Economy in the Sixteenth Century. University of California Press.

Walsh, K. (2005). Risk and marginality at high altitudes: New interpretations from fieldwork on the Faravel plateau, Hautes-Alpes. Antiquity 79: 289-305.
Walsh, K., and Giguet-Covex, C. (2019). A History of Human Exploitation of Alpine Regions. Encyclopedia of the World's Biomes. https://doi.org/10.1016/B978-0-12-409548-9.11908-6.

Walsh, K. and Mocci, F. (2002). Document Final de Synthèse, sondage archéologiques sur trois sites d'altitude de la montagne de Faravel et de l'Abri Fangeas: Faravel XIX, Fangeas VI et Fangeas VII, et Prospection-Inventaire dans La Haute Vallée de Chichin. Unpublished report.

Walsh, K., Court-Picon, M., de Beaulieu, J.-L., et al (2014). A Historical Ecology of the Ecrins (Southern French Alps): Archaeology and Palaeoecology of the Mesolithic to the Medieval Period. Quaternary International 353: 52-73.

Publisher's Note Springer Nature remains neutral with regard to jurisdictional claims in published maps and institutional affiliations. 